Praktyka Teoretyczna nr 1/2010

5. Autorefleksja Uniwersytetu - Wspólnota 
www.praktykateoretyczna.pl

\section{Research and Destroy}

\section{Communiqué z nieobecnej przyszłości - o kresie życia studenckiego ${ }^{1}$}

\section{Wprowadzenie: 7 przeciw Pompejom!}

Żyjemy jako martwa cywilizacja. Nie możemy wyobrazić sobie dobrego życia inaczej niż jako serii spektakli, wybranych uprzednio ku naszej konfuzji: połyskliwe menu iluzji. Wypełnione życia, tak jak i nasze własne imaginacje, zastępowano systematycznie zestawem obrazów, obfitszych i bardziej nieludzkich niż cokolwiek, co bylibyśmy w stanie pojąć, i tak samo nieosiagalnych. Nikt już dtużej nie wierzy w takie rezultaty.

Prawdą życia, które czeka na nas po studiach jest marna i małostkowa rywalizacja o zasoby z naszymi przyjaciółmi i nieznajomymi: gonitwa za niższymi stanowiskami kierowniczymi, wystarczającymi (przy odrobinie szczęścia) na kilka lat przepełnionych lękiem, strachem i rosnącym wyzyskiem - dopóki firma nie upadnie, a my nie zaczniemy mamrotać o „planie B”. To właśnie precyzyjny opis dzisiejszego życia uniwersyteckiego; marne i małostkowe

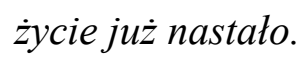

Po to tylko, by przetrwać, jesteśmy zmuszeni przyjmować rozmaite postawy względem tego rozszczepienia na niewypłacalne obietnice i oferowaną rzeczywistość. Niektórzy przyjmują naiwnie romantyczną postawę względem edukacji jako celu samego w sobie, przekonując samych siebie, że nie oczekują niczego więcej. Inni zaś postępują z żelaznym cynizmem i pogardą, ścigając się w jakiejś niedorzecznej farsie po ostatni plik banknotów w dusznej krypcie przyszłości. Jeszcze inni pozostają wierni antycznej wierze w to, że ich ciężka praca $\mathrm{z}$ pewnością zostanie któregoś dnia wynagrodzona. Muszą tylko działać, jak gdyby wierzyli - pozując na zebraniach, zdobywając kolejne tytuły, zaciagając więcej długów, pracujac ciężej.

Czas, rzeczywisty materiał naszego istnienia, znika: godziny naszego codziennego życia. Naszą przyszłość na starcie przechwycono i przekazano do obsługi długu czy żebrania wśród naszych sąsiadów. Być może uzyskamy rentę za naszą nudę? Nie ma się co łudzić. Nie będzie siedemdziesięciu siedmiu dziewic, nawet plazmowego monitora, na którym można by obejrzeć ostatnie podrygi Stanów Zjednoczonych w roli globalnego mocarstwa. Kapitalizm stat się wreszcie prawdziwa religia, w której bogactwa niebios sq obiecywane wszędzie, a nie docieraja nigdzie. Jedyną różnicą jest to, że do każdego wyrazu okropności i okrucieństwa

\footnotetext{
${ }^{1}$ Oryg. Communique from an Absent Future: On the Terminus of Student Life.
} 
zachęca się aktywnie w międzyczasie, który zdaje się nie mieć końca. Żyjemy jako martwa cywilizacja, ostatni mieszkańcy Pompejów.

Romantyczna naiwność, żelazny cynizm, pogarda i zaangażowanie. Uniwersytet i życie, które reprodukuje, wciąż na nich polegają. Liczą na nasze ludzkie zdolności do przetrwania oraz finansowego wspierania tej światowej katastrofy jeszcze przez kilka następnych lat. Dlaczego jej nie przyspieszyć? Uniwersytet przegnił od środka: „kapitał ludzki” kadry, nauczycieli oraz studentów nie byłby w stanie go już więcej bronić, tak jak nie mógłby bronić miasta umarłych.

Romantyczna naiwność, ironiczny cynizm, pogarda i zaangażowanie; nie musimy ich porzucać! Uniwersytet zmusił nas do uczenia się ich w roli narzędzi; powrócą jednak jako broń. Uniwersytet, który czyni nas niemymi i tępymi instrumentami jego własnej reprodukcji, musi zostać zniszczony, abyśmy mogli wytwarzać nasze własne życie. Romantyczna naiwność co do możliwości; żelazny cynizm odnośnie metod; pogarda dla upokarzających kłamstw o sytuacji i dobrych intencjach uniwersytetu; zaangażowanie w całkowitą transformację - nie tyle uniwersytetu, co naszego własnego życia. Oto początek powrotu wyobraźni. Musimy ponownie zacząc się organizować, uwolnić się od zamrożonej historii, od wulkanicznego fryzu naszego pogrzebanego życia.

Musimy żyć naszym własnym czasem, naszymi własnymi możliwościami. To są jedyne prawdziwe uzasadnienia istnienia uniwersytetu, chociaż nigdy ich nie wypełniał. Po jego stronie: biurokracja, inercja i niekompetencja. Po naszej stronie: wszystko inne.

I

Podobnie jak społeczeństwo, którego był wiernym sługą, uniwersytet jest w stanie upadłości. Nie jest to wyłącznie bankructwo finansowe. To wskaźnik zasadniczej niewypłacalności, zarówno politycznej, jak i ekonomicznej, tworzącej się od dłuższego czasu. Nikt nie wie już, po co jest uniwersytet. Czujemy to intuicyjnie. Przeminął stary projekt stworzenia wykształconych i wyedukowanych obywateli; przeminęła także wyjątkowa przewaga, jaką miał na rynku pracy posiadacz dyplomu. Obecnie są to fikcje, widmowe resztki, które trzymają się kurczowo nędznie utrzymywanych sal wykładowych.

Niedostosowana architektura, duchy minionych ideałów, perspektywa martwej przyszłości: oto pozostałości uniwersytetu. Większość z nas to pośród nich niewiele więcej niż zbiór gderliwych nawyków i obowiązków. Przechodzimy przez mechanizmy naszych egzaminów i zaliczeń $\mathrm{z}$ czymś $\mathrm{w}$ rodzaju bezmyślnego, niezmiennego posłuszeństwa, wspartego 
www.praktykateoretyczna.pl

bezdźwięcznym resentymentem. Nic nie jest interesujące, nic nie daje się odczuć. Światohistoryczność ze swoim korowodem katastrof nie jest bardziej realna niż okna, w których się pojawia.

Dla tych, których młodość została zatruta przez nacjonalistyczną histerię - efekt 11 września - dyskurs publiczny to nic innego, jak szereg kłamstw, a przestrzeń publiczna to miejsce, gdzie coś może eksplodować (choć nigdy tego nie robi). Dotknięci mglistym pragnieniem, by coś się wydarzyło - pozbawieni myśli, że sami moglibyśmy się do tego przyczynić - zostaliśmy uratowani przez mdłą homogeniczność Internetu, znajdując schronienie wśród przyjaciół, których nigdy nie widzimy, których cała egzystencja jest serią okrzyków i głupich obrazków, a ich jedynym dyskursem - gadanina towarów. Komfort i bezpieczeństwo stały się zatem naszymi sloganami. Ślizgamy się przez cielesny świat, nie będąc dotknięci ani poruszeni. Przeganiamy naszą pustkę z miejsca na miejsce.

Możemy być jednak wdzięczni za naszą nędzę: demistyfikacja jest teraz naszą kondycją, nie projektem. Życie uniwersyteckie wreszcie objawia sie jako to, czym od zawsze jest: jako maszyna do produkcji posłusznych producentów i konsumentów. Nawet wypoczynek jest rodzajem szkolenia do pracy. Zgraja idiotów z bractw studenckich doprowadza się alkoholem do otępienia, z oddaniem charakterystycznym dla prawników siedzących do późna w biurze. Dzieci, które paliły trawkę i chodziły na wagary w liceum, teraz wrzucają Adderall ${ }^{2}$ i biorą się do pracy. Zasilamy fabrykę dyplomów na bieżniach ${ }^{3}$ w siłowni. Biegamy niestrudzenie po eliptycznych kręgach.

Nie ma zatem większego sensu myśleć o uniwersytecie jako o wieży z kości słoniowej w Arkadii, jako o czymś idyllicznym albo jałowym. „Pracuj ciężko, baw się ostro” stało się nadgorliwym mottem pokolenia trenowanego...do czego? - do rysowania serduszek w piance na cappuccino albo wklepywania nazwisk i liczb do baz danych. Praca lśniącej technoprzyszłości amerykańskiego kapitalizmu dawno już została zakończona i sprzedana Chinom za kilka lat pożyczania tandety więcej. Dyplom uniwersytecki nie jest dziś wart więcej niż akcja General Motors.

Pracujemy i zapożyczamy się, aby pracować i zapożyczać się. Stanowiska, do których aspirujemy, to te, które już zajmujemy. Blisko trzy czwarte studentów pracuje w trakcie studiów, niejeden na cały etat; dla większości z nich poziom zatrudnienia, jaki osiagają podczas studiów, nie różni się od tego, jaki czeka ich po otrzymaniu dyplomu. Tymczasem

\footnotetext{
${ }^{2}$ Środek wspierający leczenie nadpobudliwości psychoruchowej i zaburzeń uwagi [przyp. tłum.].

${ }^{3} \mathrm{~W}$ oryginale gra słów. 'Treadmills' oznacza zarówno bieżnię, jak i kierat - urządzenie wykorzystujące siłę pociagową zwierząt do napędu stacjonarnych maszyn rolniczych [przyp. thum.].
} 
zdobywamy raczej dług niż wykształcenie. Pracujemy, by zarobić wydane już pieniądze, a nasze przyszłe zatrudnienie zostało już sprzedane na najgorszym z możliwych rynków. Średnie zadłużenie studenta wrosło o 20 procent w pierwszych pięciu latach dwudziestego pierwszego wieku - a o 80-100 procent w wypadku studentów kolorowych. Wielkość pożyczek studenckich - liczba odwrotnie proporcjonalna do nakładów państwa na edukację wzrosła o blisko 800 procent od 1977 do 2003 roku. Za nasze pożyczone czesne kupimy przywilej uiszczania miesięcznych opłat do końca naszego życia. Tym, czego się uczymy, jest choreografia kredytu - nie możesz uczęszczać na zajęcia bez otrzymywania ofert kolejnego kawałka plastiku obciążonego na 20 procent. Wczorajsi studenci finansów kupują swoje letnie domy, płacąc ponurą przyszłością dzisiejszych studentów humanistyki.

Oto wizja, do której byliśmy przygotowywani od szkoły podstawowej. Ci z nas, którzy przybyli tutaj, by uprawomocnić własny przywilej, oddali swą młodość rzeszy nauczycieli, serii testów psychologicznych, obowiązkowej służbie publicznej - cynicznym półprawdom zebranym na pstrokatym CV. Nic dziwnego, że przystąpiliśmy do niszczenia siebie, gdy tylko udało nam się uciec od elektrycznych prętów ${ }^{4}$ rodzicielskich napomnień. Z drugiej strony ci z nas, którzy przybyli tu, by wydostać się z ekonomicznej i społecznej zapaści naszych rodzin, wiedzą, że na każdego z nas, któremu się „uda”, przypadnie dziesięciu następnych - jest to więc gra o sumie zerowej. Status socjoekonomiczny pozostaje zresztą wciąż najlepszym wskaźnikiem prognozującym osiagnnięcia studenta. Tym z nas, których demografia nazywa „imigrantami”, „mniejszościami” i „kolorowymi”, kazano wierzyć w arystokrację kompetencji i zasług. Ale zdajemy sobie sprawę, że jesteśmy nienawidzeni nie pomimo naszych zasług, ale z ich powodu. Wiemy również, że układy, poprzez które moglibyśmy uwolnić się od więzów naszego pochodzenia, odtwarzają jedynie nędzę przeszłości w teraźniejszości innych, gdzie indziej.

Jeśli uniwersytet uczy nas przede wszystkim tego, jak być dłużnikami, jak marnować naszą siłę roboczą jak paść ofiarą małostkowych niepokojów, to uczy nas tym samym bycia konsumentami. Edukacja jest towarem - jak wszystko inne, czego pragniemy, nie dbając o to. Jest rzeczą i urzeczowia swoich nabywców. Czyjaś przyszła pozycja w systemie, czyjaś relacja względem innych, kupowana jest wpierw za pieniądze, a następnie za demonstrację posłuszeństwa. Najpierw płacimy, potem „ciężko pracujemy”. I tu jest pęknięcie: jednocześnie jesteś kierującym i kierowanym, konsumentem i konsumowanym. Posłusznym jest się systemowi jako takiemu, zimnym budynkom wymuszającym służalczość. Tym, którzy

\footnotetext{
${ }^{4} \mathrm{~W}$ oryginale 'cattle prod' - pręt elektryczny do zaganiania bydła [przyp. tłum.].
} 
www.praktykateoretyczna.pl

ucza, okazywany jest cały szacunek należny zautomatyzowanemu systemowi przekazywania wiadomości. Panuje tu wyłącznie logika satysfakcji klienta: czy kurs był prosty?, czy profesor nas kręci? Czy jakikolwiek głupi dupek może dostać piątkę? Jaki jest sens zdobywania wiedzy, jeżeli może być ona przywołana kilkoma stuknięciami w klawiaturę? Kto potrzebuje pamięci, kiedy mamy Internet? Trening myśli? Bez żartów. Moralne przygotowanie? Od tego są antydepresanty.

Tymczasem studenci ostatniego roku, prawdopodobnie najbardziej politycznie oświeceni z nas, są również najbardziej posłuszni. „Powołanie”, dla którego harują, nie jest niczym innym, niż fantazją o wypadnięciu z sieci albo poza rynek pracy. Każdy z nich jest przyszłym Robinsonem Crusoe, marzącym o wyspie gospodarki odłączonej od wymogów rynku. Ale ta fikcja jest podtrzymywana przez nieustanne podporządkowywanie się rynkowi. Nie ma już najmniej choćby odczuwalnej sprzeczności między nauczaniem totalnej krytyki kapitalizmu za dnia i szlifowaniem rozmowy z pracodawcą nocą. Fakt, że przyjemność i praca to dla nas jedno, tylko ułatwia radzenie sobie z naszymi objawami. Estetyka i polityka rujnują kurtuazyjne zastąpienie ideologii historią: gorzała i sztuki piękne, kolejne seminarium o problemie bycia, równy krój czcionki, każdy piksel zapłacony przez kogoś, gdzieś, jakiegoś nie-mnie, nie-tutaj, gdzie wszystko wydaje się być dobre, a każde dobro wydaje się być osiagalne za pomocą karty kredytowej.

Studia doktoranckie to po prostu wyblakła pozostałość feudalnego systemu, zaadaptowana do logiki kapitalizmu - od rozkazujących z wysokości profesorskich gwiazd po zwarte szyki asystentów i adiunktów, zwykle celowo źle wynagradzanych. Dominuje tu pewien rodzaj monastycyzmu, z wszystkimi gotyckimi rytuałami opactwa benedyktyńskiego i wszystkimi dziwnymi teologicznymi roszczeniami do szlachetności tej pracy, jej zasadniczego altruizmu. Podwładni, nad wyraz szczęśliwi, odgrywają uczniów przed mistrzami, niezdolni do kalkulacji wykazującej, że dziewięć dziesiątych z nas będzie prowadzić po cztery kursy w każdym semestrze po to, by dołożyć się do pensji jednej dziesiątej utrzymujących fikcję, że każdy może być nimi. Oczywiście to ja będę gwiazdą, to ja dostanę stały etat $\mathrm{w}$ dużym mieście i przeniosę się do ledwie wzniesionego sąsiedztwa nuworyszy.

Kończymy interpretacja Marksowskiej jedenastej tezy o Feuerbachu: „Filozofowie rozmaicie tylko interpretowali świat; idzie jednak o to, aby go zmienić.” W najlepszym razie uczymy się umiejętności dochodzenia do granic krytyki i umierania tam - tylko po to, by niczym Feniks zacząć ponownie u korzeni pozornie niemożliwych do wykorzenienia. Podziwiamy pierwszą część tego przedstawienia: oświetla nam ono drogę. Ale chcemy 
narzędzi, by przekroczyć ten samobójczy punkt myśli - chcemy punktu jej zaczepienia w praktyce.

Ludzie, którzy uprawiają „krytykę”, są również najbardziej podatni na cynizm. Ale jeżeli cynizm jest po prostu odwróconą formą entuzjazmu, to pod spodem każdy sfrustrowany lewicowy akademik jest ukrytym radykałem. Wzruszenie ramion, mroczna twarz, skręcanie się ze wstydu podczas dyskusji nad faktem, że USA zamordowały milion Irakijczyków między 2003 a 2006 rokiem, że każda ostatnia dziesięciocentówka wyciśnięta z najbiedniejszych obywateli Ameryki jest przekazywana do sektora bankowego, że poziom morza wzrośnie, miliardy umrą i że nic nie możemy z tym zrobić - taka postawa pochodzi z poczucia uwikłania w alternatywę pomiędzy ,jest” a ,powinno być” obecnej myśli lewicowej. Powszechne jest poczucie, że nie ma alternatywy, a jednak z drugiej strony, że inny świat jest możliwy.

Nie będziemy tak nadąsani. Synteza tych pozycji jest na wyciagnnięcie ręki: inny świat nie jest możliwy, jest konieczny. „Powinno być” i ,jest” są jednym. Upadek globalnej gospodarki następuje tu i teraz.

\section{II}

Nowoczesny uniwersytet nie posiada żadnej własnej historii; jego historia jest historią kapitału. Jego właściwą funkcją: reprodukcja relacji pomiędzy pracą a kapitałem. Chociaż nie jest zasadniczo korporacja, która może być kupiona lub sprzedana, która przynosi zyski swoim inwestorom, publiczny uniwersytet mimo wszystko pełni tę funkcję na tyle skutecznie, na ile to możliwe, nieustanne przybliżając się do korporacyjnej formy swoich współtowarzyszy. Tym, czego jesteśmy aktualnie świadkami, jest efekt finalny procesu, zgodnie z którym fasadowość instytucji edukacyjnych otwiera drogę do korporacyjnego zwiększania efektywności.

Nawet w złotej erze kapitalizmu, która nastąpiła po drugiej wojnie światowej i trwała aż do późnych lat sześćdziesiątych, liberalny uniwersytet był podporządkowany kapitałowi. Znajdując się na szczycie publicznego finansowania wyższej edukacji w latach pięćdziesiątych, uniwersytet był już przekształcany po to, by produkować technokratów o umiejętnościach potrzebnych do zwyciężenia „komunizmu” i utrzymywania hegemonii USA. Jego rola $\mathrm{w}$ trakcie zimnej wojny polegała na legitymizowaniu liberalnej demokracji i reprodukowaniu wyobrażonego społeczeństwa wolnych i równych obywateli - właśnie dlatego, że nikt nie byt wolny i równy. 
www.praktykateoretyczna.pl

Jeśli jednak ta ideologiczna funkcja uniwersytetów publicznych po drugiej wojnie światowej była całkiem dobrze ugruntowana, sytuacja zmieniła się w latach sześćdziesiątych i żadna ilość społeczno-demokratycznych podrygów nie przywróciłaby martwego świata powojennej koniunktury. Pomiędzy 1965 a 1980 rokiem wskaźniki zysków zaczęły spadać, wpierw w USA, następnie w pozostałej części uprzemysłowionego świata. Jak się okazało, kapitalizm nie był w stanie utrzymać wysokiego poziomu życia, który początkowo umożliwił. Dla kapitału obfitość objawia się jako nadprodukcja, wolność od pracy jako bezrobocie. Począwszy od lat siedemdziesiątych kapitalizm wkroczył w schyłkowy okres, w którym pracę stałą poddano uelastycznieniu, płaca klasy pracującej uległa stagnacji, podczas gdy ci na szczycie byli okresowo wynagradzani za ich tajemniczą finansową nekromancję, która sama wykazała swoją bezzasadność.

Dla edukacji publicznej długi okres schyłkowy oznacza spadek przychodów z podatków zarówno $\mathrm{z}$ powodu zniżkujących wskaźników wzrostu ekonomicznego, jak i uprzywilejowania cięć podatkowych dla osaczonych korporacji. Napad na kasę publiczną poraził Kalifornię i resztę narodu w latach siedemdziesiątych. Uderzał dalej wraz z każdym odchyleniem w dół cyklu biznesowego. Chociaż uniwersytet i jego wyniki nie są uzależnione od rynku, to jednak poddane są tej samej, co inne gałęzie przemysłu, logice redukcji kosztów: obniżające się wpływy z podatków sprawiły, że uelastycznienie pracy stało się nieuchronne. Emerytowani profesorowie, zamiast na stałych stanowiskach, mają możliwość zatrudnienia na niepewnych posadach asystentów, adiunktów i wykładowców, wykonujących tę samą pracę za mniejszą płacę. Zwiększające się czesne jest kompensatą za budżetowe cięcia, podczas gdy stanowiska, które zagwarantować ma opłacany przez studentów proces kształcenia, ulatniają się.

W środku aktualnego kryzysu, który będzie długi i przewlekły, wielu na lewicy żąda powrotu złotej ery edukacji publicznej. Naiwnie wyobrażają sobie, że kryzys teraźniejszości jest okazją, by żądać powrotu przeszłości. Jednak programy socjalne, które uzależnione są od wysokich wskaźników zysku i żywotnego wzrostu ekonomicznego, przepadły. Nie możemy ulegać pokusie daremnego chwytania się tego, co stracone, ignorując jednocześnie oczywisty fakt, że w kapitalistycznym społeczeństwie nie może istnieć autonomiczny „uniwersytet publiczny”. Uniwersytet jest poddany prawdziwemu kryzysowi kapitalizmu, a kapitał nie potrzebuje liberalnych programów edukacyjnych. Zadaniem uniwersytetu od zawsze była reprodukcja klasy pracującej poprzez trenowanie przyszłych pracowników dostosowanych do zmieniających się żądań kapitału. Dzisiejszy kryzys uniwersytetu jest kryzysem reprodukcji klasy pracujacej, kryzysem okresu, w którym kapitat nie potrzebuje nas dtużej jako 
pracowników. Nie uwolnimy uniwersytetu od wymagań rynku, nawołując do powrotu publicznych systemów edukacji. Za naszego życia logika rynku, na której ten system został zbudowany, dociera do swojego ostatniego przystanku. Jedyna autonomia, na której osiagnięcie możemy mieć nadzieję, istnieje poza kapitalizmem.

Dla naszych zmagań oznacza to, że nie możemy zrobić kroku wstecz. Niegdysiejsze walki studenckie są reliktami świata, który zniknął. W latach sześćdziesiątych, gdy tylko zaczęto pojmować powojenny boom, zamknięci w murach uniwersytetu radykałowie zrozumieli, że inny świat był możliwy. Mając dość technokratycznego zarządzania, żądając zerwania łańcuchów konformistycznego społeczeństwa oraz odmawiając alienującej pracy, niekoniecznej $\mathrm{w}$ wieku przepychu, studenci próbowali sprzymierzyć się z radykalnymi odłamami klasy pracującej. Jednak ich sposób radykalizacji, zbyt mizernie związany z ekonomiczną logiką kapitalizmu, uniemożliwił utrzymanie się tego wiązania. Ponieważ ich opór wobec wojny w Wietnamie skupiał się na krytyce kapitalizmu jako kolonialnej machiny wojennej, niewystarczająco jednak na kapitalistycznym wyzysku rodzimej pracy, studenci z łatwością wzięli rozbrat z klasą pracująca, stawiającą czoła innym problemom. U zmierzchu ery powojennego boomu uniwersytet nie był podporządkowany kapitałowi w takim samym stopniu, jak teraz, a studenci nie byli tak intensywnie proletaryzowani przez dług $\mathrm{i}$ zdewastowany rynek pracy.

$\mathrm{Z}$ tych powodów nasza walka jest całkowicie inna. Ubóstwo życia studenckiego stało się ostateczne: nie ma już obietnicy wyjścia. Jeśli kryzys ekonomiczny lat siedemdziesiątych wyłonił się po to, by zatrzymać kryzys polityczny lat sześćdziesiątych, to fakt, że dziś kryzys ekonomiczny poprzedza nadchodzące powstanie polityczne, oznacza, że możemy nareszcie wyprzeć kooptację i neutralizację wcześniejszych walk. Nie będzie żadnego powrotu do normalności.

\section{III}

Poszukujemy sposobu popchnięcia walki uniwersytetu do jej granic.

Chociaż oskarżamy prywatyzację uczelni i autorytarny system zarządzania nią, nie poszukujemy reform strukturalnych. Nie żądamy wolnego uniwersytetu, ale wolnego społeczeństwa. Wolny uniwersytet w środku kapitalistycznego społeczeństwa jest jak czytelnia w więzieniu; służy jedynie oderwaniu się od marności codziennego życia. Zamiast tego szukamy kanału ujścia dla gniewu wywłaszczonych studentów i pracowników, prowadzącego aż do deklaracji wojny. 
www.praktykateoretyczna.pl

Musimy zacząć od powstrzymania funkcjonowania uniwersytetów. Musimy zakłócić normalny przepływ ciał i rzeczy, doprowadzając pracę i klasę do zatrzymania się. Będziemy blokować, okupować i brać to, co nasze. Widzimy te zakłócenia raczej jako to, co mamy do powiedzenia, to, jak mamy być rozumiani, niż jako przeszkody we wzajemnym dialogu i rozumieniu. Jest to jedyna sensowna postawa w czasach, gdy kryzys obnażył sprzeczne interesy leżące u podstaw społeczeństwa. Wołanie o zjednoczenie się jest zasadniczo puste. Nie ma wspólnego gruntu dla tych, którzy podtrzymują status quo i tych, którzy chcą go zniszczyć.

Uniwersytecka walka jest jedną spośród wielu innych, odbywających się w miejscach pracy, dzielnicach i slumsach, gdzie mają swoje źródło nowe cykle odmowy i oporu. Losy nas wszystkich są połączone i nasz ruch będzie musiał dołączyć do innych, rozsadzając ściany uniwersyteckich przestrzeni i rozlewając się po ulicach. Ostatnimi tygodniami nauczyciele szkół publicznych w Bay Area, pracownicy BART i bezrobotni zagrozili strajkami oraz demonstracjami. Każdy z tych ruchów jest odpowiedzią na różne aspekty ożywionych ataków kapitalizmu na klasę pracująca w chwili kryzysu. Każdy z nich rozpatrywany osobno wydaje się mały, krótkowzroczny, pozbawiony nadziei na powodzenie. Jednak wzięte razem wskazują na możliwość powszechnej odmowy i oporu. Naszym zadaniem jest rozjaśnienie wspólnych warunków, które niczym ukryte lustro wody zasilą swą mocą każdą walkę.

Widzieliśmy już w nieodległej przeszłości tego rodzaju erupcję, rebelię, która zaczyna się w klasach szkolnych i promieniuje na zewnątrz, by objąć całość społeczeństwa. Zaledwie dwa lata temu ruch przeciwników CPE we Francji ${ }^{5}$, zwalczający nowe prawo, które pozwalało pracodawcom zwalniać młodych pracowników bez podania przyczyny, doprowadził do olbrzymich demonstracji na ulicach. Licealiści i studenci, nauczyciele i rodzice, szeregowi działacze związkowi i bezrobotna młodzież z banlieues $^{6}$ znaleźli się razem po tej samej stronie barykady. (Solidarność między nimi była jednak zazwyczaj krucha. Zamieszki młodych imigrantów na przedmieściach i studentów w centrach miast nigdy nie stopiły się $\mathrm{W}$ całość i z czasem napięcia pomiędzy nimi zaogniły się.) Dostrzegając iluzoryczność uniwersytetu jako azylu i miejsca oświecenia, francuscy studenci zrozumieli, że byli po prostu trenowani do pracy. Wyszli na ulice jako pracownicy, protestując przeciw

\footnotetext{
${ }^{5} \mathrm{CPE}$ - Contrat première embauche [Pierwsza umowa o pracę] - regulacja, która według francuskiego rządu miała spowodować wzrost ilości miejsc pracy dla ludzi poniżej 26 roku życia, w rzeczywistości deregulowała rynek zatrudnienia, dając pracodawcy możliwość, by w ciagu dwóch pierwszych lat zatrudnienia miał możliwość zwolnienia ze stanowiska bez podania żadnej przyczyny. W lutym 2006 roku na ulicach i uniwersytetach we Francji rozpoczęły się protesty i okupacje. Opór trwał trzy miesiące. W odróżnieniu od studenckich wystąpień i ruchów po Maju 1968 , ruch anty-CPE wysuwał żądania dotyczące reorganizacji całości stosunków społecznych, a nie jak do tej pory, tylko kwestii edukacyjnych i związanych z uczelnią [przyp. tłum.]. ${ }^{6} \mathrm{Z}$ franc. przedmieścia [przyp. tłum.].
} 
niepewności swej przyszłości. Ich pozycja zburzyła podział pomiędzy szkołą a miejscem pracy i natychmiast zdobyła wsparcie wielu pracowników najemnych oraz bezrobotnych w masowym akcie proletariackiej odmowy.

$\mathrm{W}$ toku swojego rozwoju ruch manifestował wzrastające napięcie pomiędzy rewolucją a reformą. Jego forma była bardziej radykalna niż jego treść. Podczas gdy retoryczne zabiegi studenckich liderów skupiały się wyłącznie na powrocie do status quo, działania młodzieży zamieszki, poprzewracane i podpalone samochody, blokady dróg i linii kolejowych, fale okupacji zamykające szkoły i uniwersytety - oznajmiły skalę rozczarowań i gniewu nowej generacji. Wbrew temu wszystkiemu ruch rozpadł się jednak, gdy prawo CPE zostało ostatecznie odrzucone. Chociaż najbardziej radykalna część ruchu szukała możliwości rozprzestrzenienia rebelii i przekształcenia jej w ogólną rewolucję przeciwko kapitalizmowi, nie była ona w stanie zapewnić sobie znaczącego poparcia, tak że demonstracje, okupacje, blokady osłabły i szybko wygasły. Ostatecznie ruch nie był zdolny do przekroczenia ograniczeń reformizmu.

Greckie powstanie $\mathrm{z}$ grudnia 2008 roku zerwało $\mathrm{z}$ wieloma ograniczeniami i wyznaczyło początek nowego cyklu walki klasowej. Na powstanie, rozpoczęte przez studentów w odpowiedzi na zamordowanie młodego chłopaka przez ateńską policję, złożyły się tygodnie zamieszek, plądrowania sklepów, okupacji uniwersytetów, central związkowych i stacji telewizyjnych. Płonęły całe dzielnice finansowe i handlowe, a niewystarczającą liczebność ruch rekompensował swoim geograficznym rozmachem, rozszerzając się od miasta do miasta, aż do ogarnięcia całej Grecji. Podobnie jak we Francji, było to powstanie młodzieży, dla której kryzys ekonomiczny oznaczał całkowite zanegowanie przyszłości. Protagonistami byli studenci, niepewni pracownicy, imigranci, którzy byli w stanie osiagnąć poziom jedności dalece przerastający kruchą solidarność ruchu anty-CPE.

Co równie ważne, nie stawiali praktycznie żadnych żądań. Choć oczywiście niektórzy demonstranci chcieli reformy systemu policyjnego lub krytykowali niektóre rządowe działania, generalnie nie wymagali niczego od rządu, uniwersytetu, pracodawców czy policji. Nie dlatego, że uważali to za lepszą strategię, ale dlatego, że chcieli czegoś, czego żadna z tych instytucji nie mogła im zaoferować. W tym wypadku treść była uzgodniona z formą; podczas gdy optymistyczne slogany, które pojawiały się wszędzie na francuskich demonstracjach, kontrastowały z obrazami płonących samochodów i stłuczonych szyb, w Grecji zamieszki były oczywistym środkiem do wcielenia w życie całkowitego zniszczenia sytemu politycznego i ekonomicznego. 
www.praktykateoretyczna.pl

Ostatecznie dynamika, która wytworzyła powstanie, ustanowiła również jego granicę. Było to możliwe dzięki istnieniu pokaźnej infrastruktury radykalnych ośrodków na terenach miejskich, w szczególności Exarchei, jednej z ateńskich dzielnic. Squaty, bary, kawiarnie, centra społeczne odwiedzane przez studentów i imigrancką młodzież, stworzyły środowisko, w którym zrodziło się powstanie. Jednakże to środowisko było obce pracownikom zarobkowym w średnim wieku, którzy nie postrzegali tej walki jako własnej. Niezależnie od wielu wyrazów solidarności z protestującą młodzieżą postrzegali ją jako ruch początkujących - czyli tę część proletariatu, która poszukuje sposobu wejścia na rynek pracy, ale nie w urzędowym, pełnowymiarowym czasie pracy. Powstanie, chociaż silne na uczelniach i imigranckich przedmieściach, nie rozprzestrzeniło się na zakłady pracy.

Naszym zadaniem w bieżącej walce będzie rozjaśnienie sprzeczności pomiędzy formą i treścią oraz stworzenie warunków do przekroczenia reformistycznych roszczeń, jak również wprowadzenie treści prawdziwie komunistycznej. Tak jak związki, studenci i grupy wydziałowe odrzucili swoje różne ,problemy”, również my musimy zwiększać napięcie, póki nie stanie się jasne, że chcemy czegoś całkowicie innego. Musimy nieustannie ukazywać niespójność roszczeń demokratyzacji i jawności. Cóż jest dobrego w posiadaniu prawa do dostrzegania, jak bardzo nie do zaakceptowania jest stan rzeczy, czy do wybierania tych, którzy i tak nas wystawią? Musimy zostawić za sobą kulturę studenckiego aktywizmu, z jej moralistycznymi mantrami o pokojowych rozwiązaniach i fiksacją na pojedynczych sprawach. Jedynym sukcesem, który może nas zadowolić, jest zniesienie kapitalistycznego sposobu produkcji i właściwego mu spychania w nędzę i śmierć, które przyobiecał nam na dwudziesty pierwszy wiek. Wszystkie nasze działania muszą kierować nas w stronę uwspólnotowienia, czyli reorganizacji społeczeństwa zgodnie z logiką wolnego darowania i otrzymywania; natychmiastowego zniesienia płac, formy wartości, obowiązkowej pracy i wymiany.

Okupacja będzie w naszej walce taktyką krytyki, ale musimy stawić czoło tendencji używania jej w reformistyczny sposób. Różne strategiczne użycia okupacji stały się jasne w minionym styczniu, kiedy studenci okupowali budynek New School w Nowym Yorku. Grupa przyjaciół, głównie absolwentów, zdecydowała się przejąć Centrum Studenckie i ogłosić je wyzwoloną przestrzenią dla studentów i społeczności. Wkrótce przyłączyli się do nich następni, z których wielu wolało jednak wykorzystać tę akcję jako dźwignię do przeprowadzenia reform, w szczególności do usunięcia dyrektora szkoły. Różnice te osiagnęły punkt kulminacyjny, kiedy okupacja się rozwinęła. Podczas gdy reformistyczni studenci obstawali przy warunku opuszczenia budynku po uzyskaniu konkretnych ustępstw ze 
strony administracji, inni całkowicie wystrzegali się jakichkolwiek żądań. Postrzegali okupację jako chwilową wyrwę w kapitalistycznym czasie i przestrzeni, zmianę, która nakreśliła kontury nowego społeczeństwa. Jesteśmy po stronie anty-reformistów. Chociaż zdajemy sobie sprawę, że te wolne przestrzenie będą częściowe i krótkotrwałe, to jednak eksponowane przez nie napięcie pomiędzy tym, co rzeczywiste, a tym, co możliwe, może skierować walkę w bardziej radykalną stronę.

Zamierzamy stosować tę taktykę dopóty, dopóki nie zostanie ona uogólniona. W 2001 roku pierwsi argentyńscy piqueteros wskazali formę, jaką powinny tam przybrać walki ludowe: blokady ulic, powodujące paraliż przemieszczania dóbr z miejsca na miejsce. W ciagu miesięcy taktyka ta rozprzestrzeniła się na cały kraj bez żadnej formalnej koordynacji między grupami. W ten sam sposób powtórzenie może ustanowić okupację jako instynktowną i natychmiastową metodę rewolty, którą można zastosować zarówno wewnątrz, jak i na zewnątrz uniwersytetu. Przez ostatni rok w USA widzieliśmy nową falę przejęć, zarówno na uniwersytetach, jak i w miejscach pracy: New School i New York University, jak również pracownicy Republic Windows Factory w Chicago, którzy walczyli przeciw zamknięciu ich fabryki poprzez jej zajęcie. Teraz nasza kolej.

By osiagnąć nasze cele, nie możemy polegać na grupach, które ustawiają się w roli naszych reprezentantów. Chcielibyśmy współpracować ze związkami i zrzeszeniami studenckimi wtedy, gdy uznamy to za użyteczne; nie uznamy jednak ich autorytetu. Musimy działać bezpośrednio w naszym własnym imieniu, bez żadnych mediacji. Musimy zerwać ze wszystkimi grupami, które starają się ograniczać walkę, nakłaniając nas do powrotu do pracy czy sal wykładowych, negocjowania lub pojednania. Tak samo było we Francji. Źródłowe wezwanie do protestu wychodziło od państwowych szkół średnich, uniwersyteckich stowarzyszeń studenckich i niektórych związków zawodowych. Ostatecznie, kiedy grupy przedstawicielskie nawoływały do spokoju, inni posuwali się jeszcze dalej. W Grecji związki ujawniły swój kontrrewolucyjny charakter, odwołując strajki i wzywając do pohamowania.

Jako alternatywę wobec bycia traktowanym przez przedstawicieli jak trzoda, wzywamy studentów i robotników do samodzielnego organizowania się w poszczególnych sektorach produkcji. Nakłaniamy absolwentów, asystentów, wykładowców, wydziały i pracowników pionu technicznego do rozpoczęcia wspólnych spotkań i dyskutowania własnej sytuacji. Im więcej będziemy rozmawiać ze sobą i poszukiwać naszego wspólnego interesu, tym trudniejsze stanie się dla administracji zwrócenie nas przeciw sobie nawzajem w beznadziejnym konkurowaniu o kurczące się zasoby. Ostatnie walki w NYU i New School ucierpiały przez brak tych głębokich więzi i jeśli możemy się czegoś z nich nauczyć, to tego, 
www.praktykateoretyczna.pl

że konieczna jest budowa zwartych sieci solidarności w oparciu o rozpoznanie wspólnego wroga. Sieci te nie tylko uodpornią nas na przywracanie do normalności i neutralizację, ale również pozwolą nam ustanowić nowy rodzaj kolektywnych więzi. To one stanowią rzeczywistą podstawę naszej walki.

Widzimy się na barykadach.

Reaserch and Destroy

Październik 2009

Key Words: university, crisis, communism, community, students protests.

przełożyli Krystian Szadkowski, Maciej Szlinder 